\title{
Investigation of The Influence of Sharia Principles Implementation on Business Development and Customer Loyalty
}

\author{
Mahyarni $^{1}$,Astuti Meflinda ${ }^{2}$, Khairil Anwar $^{3}$, Hasrudy Tanjung ${ }^{4}$ \\ \{Mahyarni@uin-suska.ac.id ${ }^{1}$ \} \\ 1,2,3 Universitas Islam Negeri Sultan Syarif Kasim RIAU, Pekan Baru,Indonesia \\ ${ }^{4}$ University of Muhammadiyah Sumatera Utara, Medan, Indonesia
}

\begin{abstract}
This study aims to examine and analyse the influence of the Implementation of Sharia Principles on Business Development, Application of Sharia Principles on Customer Loyalty, and Sharia Business Development on Customer Loyalty. This research was conducted in Pekanbaru City which is the capital of Riau Province. Riau Province is the closest province to Malaysia and Singapore which is incorporated in Growth Triangle. The number of samples in this study consists of 60 SMEs in which the business is focused on food business with Purposive sample technique. Data analysis was conducted by using Partial Least Square. The results showed that the implementation of Sharia Principles has an effect on encouraging the increase of Business Development, and the Implementation of Sharia Principles do not influence the increase of Customer Loyalty, and the Sharia Business Development influenced the increase of Customer Loyalty.
\end{abstract}

Keywords: Sharia principles, Business development, Loyalty, Customer

\section{Introduction}

Along with the increasing of the awareness Indonesian people with Muslim majority to use and utilize halal and barokah products of goods and services, the role of sharia-based company is becoming a promising alternative in the future. Perhaps this phenomenon is considered too optimistic, but the fact the trend today is going to that way. Religion brand is the way of sharia product development now, although the market segment is more specific and more segmented, and it is really possible in the short future will be the most needed product by all people, not only for Muslim people but also for non Muslim community.

In the last five years, the development of business with Islamic background is more interesting and gladden, although we know that the business development is limited in bank, insurance, micro finance, and education. These things are interesting phenomenon to be observed. Likewise with big companies, the 21 st century models, have new trend to implement business ethics as community vision responsible socially and economically. This reality is approved by research result conducted by (Liebig, 1994), the writer of Merchants of Vision. In that research, he interviewed business figures in 14 (fourteen) countries. James Liebig found 6 (six) generally applied perspectives: 1) Act based on ethics, 2) Heighten social justice, 3) Protect surroundings, 4) Empowering human creativity, 5) Deciding social vision and aims of business and involving workers in building a better business world, creating affection and good service in company process, and 6) Reviewing classic view about paradigm of economy which is valued-free. These perspectives show that business ethics in which only idols up till now is becoming easier to realize as fact now.

The implementation of Sharia principles and business development closely related to customer satisfaction in which reflecting loyalty in using the product. Loyalty according to 
(Griffin, 2002) is: "customer routine purchase based on decision making unit. Pekanbaru as the capital and the biggest city in Riau Province is a service city with Sultan Syarif Kasim II Airport as the gate. Pekanbaru also has several tourism objects and cultures with high fascination for local, national, and international tourists. Business activity in Pekanbaru is more rapid and as the business center with the densest population aiming to open new business and finding jobs.

Problems in this research are to examine and analyze the effects of Sharia principles toward the development of Sharia business, to examine and analyze the effects of Sharia business development toward customer loyalty, and to examine and analyze the effects of the implementation of Sharia principles toward customer loyalty. Beside this, the result of this research aims to formulate policy develop Sharia SMEs in the future.

This research is the perfection of research conducted by (Rohmah, 2014) and (Jalil, 2010) regarding the implementation of values of Islamic business ethics in organizations, whereas this research focused on reviewing the effects of inter variables in the implementation of Sharia principles, the development of business and customer loyalty. Besides, the indicators and analysis tools are also different and in the previous research, the analysis was conducted as qualitative, whereas this research uses quantitative analysis with Partial Least Square approach. This research is also expected to give distinctive color for the development of Sharia business development in the future.

\section{Theory}

\subsection{Implementation of Sharia Principles}

In term, Sharia means law descended from Allah Subhanahu wa Ta'ala through Rasulullah Muhammad Shalallahu 'alaihi wa Sallam for all human beings regarding worship, morals, food, drink, clothes, and muamalah (interaction among human beings in all aspects of life) as to reach happiness in the world and the hereafter. According to (Antonio, 2001), Sharia has its own uniqueness in which not only comprehensive, but also universal. Universal means that Sharia can be implemented all the time and places by everybody. This universality mainly can be seen in social (economic) aspect in which it is not distinguishing Muslim and non-Muslim. Sharia business has 5 (five) principles in conducting its economic activities (Beekun, 1996):

1. Unity

Unity is reflected in Tauhid concept which combining all aspects in a Muslim's life, whether it is economy, politics, social, becoming homogeneity and emphasizing consistence concept and overall regularity.

2. Justice

In doing activity in the work place and business, Islam requires people to do justice, with no exception to disfavour people. This corresponds to Allah's saying in Al-Maidah:8. Justice reflects horizontal dimension of Islam learning related to all harmony to the universe.

3. Free desire

Free is an important part in ethic values of Islamic business, but the freedom does not harm collective importance. Up to certain level, human is blessed with free desire to give direction and guide their own life as the leader in this world (QS. Al-Baqarah, 2:30)

4. Responsibility 
According to Sayyid Qutu, Islamic responsibility principle is a balanced responsibility in all aspects and scopes, between soul and body, between person and family, between individual and social, and between one community and another.

5. Truth: Goodness and Honesty

Goodness in this context consists of goodness and honesty. In business context, truth here means as intention, attitude and good behavior consisting of transaction process, finding commodity.

\subsection{Development of Sharia SMEs}

(Machfoedz, 2005) states that business development is a trade conducted by a group of organized people to get profit to produce and sell goods and service to require customer's needs. Based on this definition, the business continuity is a form of consistence from a business condition, in which this continuity is a process of the ongoing business consisting of growth, development, and strategy to keep the business continuity and development disembogue in business continuity and existence. Hence, a Muslim businessman will have basic characters encouraging being creative person in running his business. These characters are:

a. Always like and realize that there is a provision and change. A provision is found in aqidah concept (QS. Al-Anbiya: 125). Whereas a change is implemented in Muamalah problems, including increasing of life quality (QS.Ar-Ra'd: 1l).

b. Innovative and creative which distinguishing him from others. Al-Quran places human beings as the leader with task to prosper the earth and to make a change and improvement; (Al-Hadis).

c. Make a serious effort to benefit others.

d. A work of effort must be built on an on going basis, not just for a moment or for the benefit of the individual, rather for a longer period of time and for future generations.

\subsection{Customer Loyalty}

The theory that explains how customer satisfaction or dissatisfaction is formed according to Mowen in (Sumarwan, 2003) is the expectancy disconfirmation model, which suggests that customer satisfaction and dissatisfaction is the impact of comparison between consumer expectations before the purchase and the actual consumer obtained from the purchased product. When a consumer buys a product, the consumer has an expectation of how the product works (product performance). Loyal customers are invaluable asset to the company, because the characteristics of loyal customers according to (Griffin, 2002), among others, make regular purchases, purchases outside the product/service line, reject other products, show immunity from the attraction of competition (not affected by the attraction of competition on similar products).

\subsection{Research Purposes}

This research aims to:

1. To examine and analyse the influence of the Implementation of Sharia Principles on Business Development.

2. To examine and analyse the influence of Sharia Principles on Customer Loyalty.

3. To examine and analyse the influence of Sharia Business Development on Customer Loyalty. 


\subsection{Hypothesis}

The research hypotheses are:

a. The implementation of Sharia principles in business can encourage the improvement of business development in the future.

b. The rapid increase of business development will encourage customer loyalty in the future.

c. The implementation of Sharia principles in business can encourage the increasing of customer's loyalty in the future.

\section{Method Of Research}

This study analyses the application of Sharia principles to Sharia Business in Pekanbaru City. Pekanbaru City is the capital of Riau Province which is bordered by Singapore and Malaysia. The population in this research is all business of Sharia SMEs which active in business activity in food product field. The sampling technique is purposive sampling technique, with the number of samples counted 60 people. The data collection technique is done by using questioner, and interview. Data analysis was done by using Partial Least Square. The operational concepts in this research are:

Table 1. Operational Research Variables

\begin{tabular}{|c|c|c|}
\hline Variables & Variable Concepts & Indicators \\
\hline $\begin{array}{l}\text { Sharia Principles } \\
\text { Implementation }\left(\mathrm{X}_{1}\right)\end{array}$ & $\begin{array}{l}\text { Its own uniqueness not only } \\
\text { comprehensive, but Sharia } \\
\text { business also has a universal nature } \\
\text { which means it can be applied } \\
\text { anytime and by anyone both } \\
\text { Muslim and non-Muslim (Antonio, } \\
\text { 2001). }\end{array}$ & $\begin{array}{ll}\text { 1. } & \text { Unity } \\
\text { 2. } & \text { Balance } \\
\text { 2. } & \text { Free Desire } \\
\text { 3. } & \text { Responsibility } \\
\text { 4. } & \text { Truth: Goodness and Honesty } \\
\text { (Summarized from various } \\
\text { sources) }\end{array}$ \\
\hline Business Development $\left(\mathrm{Y}_{1}\right)$ & $\begin{array}{l}\text { Business development is the trade } \\
\text { done by an organized group of } \\
\text { people to earn profits by producing } \\
\text { and selling goods or services to } \\
\text { meet customer needs (Machfoedz, } \\
\text { 2005) }\end{array}$ & $\begin{array}{l}\text { 1. Always liked and } \\
\text { aware of it provisions } \\
\text { and change. } \\
\text { 2. Being creative that } \\
\text { distinguish it with other } \\
\text { people } \\
\text { 3. Make a serious effort to } \\
\text { benefit others } \\
\text { 4. The use of production factor } \\
\text { directs to long term plan } \\
\text { (Summarized from various } \\
\text { sources) }\end{array}$ \\
\hline Customer's Loyalty $\left(\mathrm{Y}_{1}\right)$ & $\begin{array}{l}\text { Behavior's encouragement The } \\
\text { encouragement of conduct to repeat } \\
\text { purchase and to build customer } \\
\text { loyalty to a product / service } \\
\text { produced by the enterprise takes a } \\
\text { long time through a repeat purchase } \\
\text { process (Olson, 1993) }\end{array}$ & $\begin{array}{l}\text { 1. Purchasing regularly. } \\
\text { 2. Purchasing outside the product / } \\
\text { service line. } \\
\text { 3. Rejecting other products. } \\
\text { 4. Showing immunity from the } \\
\text { attraction of competition } \\
\text { (unaffected by the attraction of } \\
\text { competition on similar } \\
\text { products). }\end{array}$ \\
\hline
\end{tabular}


The model discussed in this research is as follows:

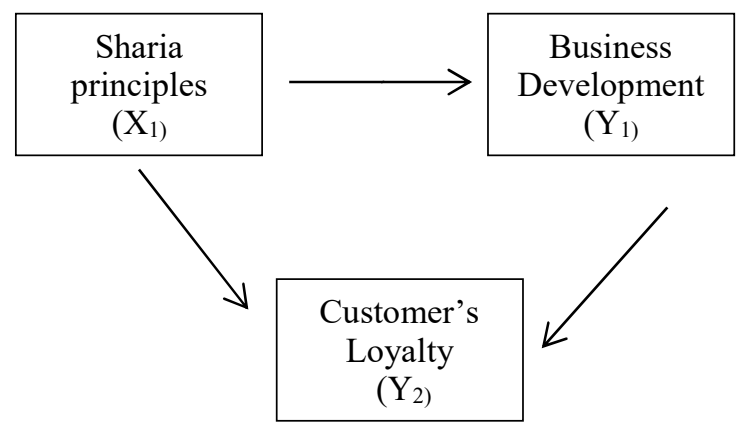

Fig. 1. Research Model

\section{Data Analysis And Discussion}

\subsection{Structural models}

Structural models created in the PLS program are as follows:

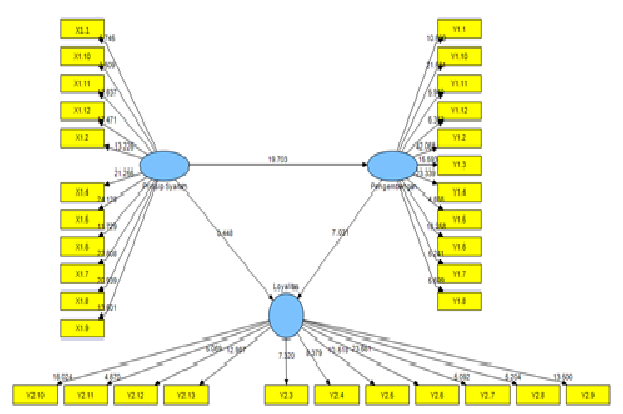

Fig. 2. PLS Output

While the results of data interpretation of the output PLS can be seen in the following table:

Table 2. Path Coefficients among Investigated Variables

$\begin{array}{ccc}\text { Construct } & \text { Original } & \text { TStatistics } \\ & \text { Sample } & (|\mathrm{O} / \mathrm{STERR}|)\end{array}$

(O)

\begin{tabular}{lcc} 
& $(\mathrm{O})$ & \\
\hline Business & 0.762 & 7.030561 \\
Development(Y1)- & 993 & \\
$>$ & & \\
Customer'sLoyalt & & \\
y (Y2) & & \\
\hline Sharia Principles & 0.679 & 0.448493 \\
\hline
\end{tabular}




\begin{tabular}{lcc}
\hline (X1) & $->$ & 094 \\
$\begin{array}{l}\text { Customer's } \\
\text { Loyalty (Y2) }\end{array}$ & & \\
\hline \multicolumn{1}{c}{ Sharia } & 0.808 & 19.70264 \\
Principles (X1)-> & 932 & 3 \\
Business & & \\
Development (Y1) & & \\
\hline
\end{tabular}

From the picture and table above, it can be seen the results of testing the structural model by looking at the influence between the following variables:

a. Influence of Implementation of Sharia Principles Variable (X1) to Business Development Variables (Y1)

Implementation of Sharia Principles Variable (X1) has a positive effect on Business Development (Y1), with coefficient value of 0.8089. This shows that if Sharia Principle Implementation (X1) increases then Business Development (Y1) will also increase. Whereas t value of variable of Sharia Principles Implementation (X1) is 19.702643 bigger than $\mathrm{t}$ table equal to 1,96, that there is a significant influence between the variables of Sharia Principles Implementation (X1) to Business Development (Y1). In other words, Sharia Principles (X1) Implementation will encourage the increasing of Business Development (Y1) variable in Pekanbaru City.

b. Influence of Implementation of Sharia Principles Variable (X1) to Customer Loyalty Variables (Y2)

Implementation of Sharia Principles Variable (X1) has a positive effect on Customer Loyalty (Y2), with coefficient value of 0.6791. This indicates that if Sharia Principle Implementation (X1) increases then Customer Loyalty (Y2) will also increase. While the value of $t$ variable implementation of Sharia Principles (X1) of 0.448493 smaller than $t$ table of 1.96, indicating that there is no significant effect between Implementation of Sharia Principles variables (X1) on Customer Loyalty (Y2). In other words, the implementation of the Sharia Principles has not encouraged the increase of Customer Loyalty in Pekanbaru City.

c. Influence Variable Business Development (Y1) to Variable Customer Loyalty (Y2) in Pekanbaru City

Business Development Variable (Y1) has a positive effect on Customer Loyalty (Y2), with coefficient value of 0.762993 . This indicates that if Sharia Principle Implementation (X1) increases then Customer Loyalty (Y2) will also increase. Whereas the value of t value of Business Development (Y1) is 7.030561 bigger than $t$ table equal to 1,96 , which is significant between Business Development variables (Y1) on Customer Loyalty (Y2). In other words, Sharia Business Development will encourage the increase of Customer Loyalty in Pekanbaru City

\subsection{Discussion of Results}

\subsubsection{Influence of Variable of Implementation of Sharia Principles (X1) to Variable of Sharia Business Development (Y1).}

The results showed that the implementation of Sharia principles encouraged the growth of sharia business in Pekanbaru city. Implementation of Sharia principles is closely related to business ethics which is the way when conducting business activities covering all aspects, 
whether it is related to an individual, company, or society. Business ethics can build and shape good values, norms and behaviours in business. In a business Ethics Company can establish good employee behaviour, and can also build good business relationships with customers and partners of SMEs. In business, all SMEs believe that good business is a business that has ethics. Businesses that comply with applicable regulations and business ethics can make guidelines for conducting work activities, based on ethics, morals, honesty and professionalism. While one of the objectives of implementing the principles of sharia in business is to provide moral awareness and provide restrictions to business actors in order to run a good business, both to customers and to employees.

Thus, the implementation of Sharia principles in business can organize and direct business people to create good management and image in business, so that the business can be followed by everyone who believes that the business has good ethics. Some of the benefits that can be gained from implementing the principles of Sharia in business are:

1. Can increase SMEs credibility.

2. Can increase SMEs competitiveness.

3. Can create positive image of SMEs.

The results of interviews with SME local doers of local food products stated that the development of local SME food products are growing and supported by facilities and infrastructure and some events are often held in Riau Province, especially Pekanbaru City. Implementation of Sharia principles in running a business also has begun to feel, one of them by getting used to discipline and friendly in serving customers

\subsubsection{Influence of Sharia Principles Implementation (X1) to Customer Loyalty (Y1).}

The results showed that the implementation of Sharia Principles has not encouraged the increase of Customer Loyalty in Pekanbaru City. At the present time both practitioners and academics understand that customer loyalty and satisfaction are related, although the linkage is not always in tandem (Oliver, 1999). Satisfaction is an important step in loyalty formation but becomes less significant when loyalty begins to emerge through other mechanisms. Other mechanisms can take the form of determination and social ties.

Loyalty has a different dimension to satisfaction. Satisfaction shows how a product meets its customer goals (Oliver, 1999). Customer satisfaction is always the main cause of loyalty. Yet other studies have found a lack of loyalty to satisfaction. (Jones \& Sasser, 1995) concluded that simply satisfying customers is not enough to keep them loyal, while they are free to make choices. (Jones \& Sasser, 1995), (Stewart, 1997) concludes it is wrong to suggest the assumption that satisfaction and loyalty are moving together. (Reichheld, 1996), suggests that from satisfied or highly satisfied customers, between $65 \%$ and $85 \%$ will move on to other products. Loyalty occurs because of the influence of satisfaction / dissatisfaction with products that accumulate continuously in addition to the perception of product quality (Boulding, et al., 1993), (Bloemer, et al., 1998) Interviews with the perpetrators of food products SMEs also states that they always serve customers in a friendly manner in accordance with Islamic religious teachings and explain in detail about the products being traded.

\subsubsection{The Effect of Business Development Variable (X2) on Customer Loyalty Variable (Y1)}

The results show that the development of sharia business will encourage increased customer loyalty in Pekanbaru City. SME business doers of food products realize that increasingly fierce competition between providers of the product lately not only due to 
globalization. But it is more because customers are getting smarter, price-conscious, demanding, less forgiving, and more products on the market. Advances in communication technology also play a role in increasing the intensity of competition, because it gives customers access to more information about the various products offered. This means that customers have more options in using the money they have. (Kotler, et al., 2002), mention there are six reasons why an institution needs to get its customer loyalty:

1. Existing customers are more prospective, meaning that loyal customers will benefit the institution greatly.

2. The cost of acquiring new customers is far greater than keeping and maintaining existing customers.

3. Customers who already believe in the institution in an affair will believe in other matters as well.

4. The cost of institutional operations will be efficient if it has many loyal customers.

5. Institutions can reduce psychological and social costs because old customers have had many positive experiences with institutions.

6. Loyal customers will always defend the institution even try also to attract and give advice to others to become customers.

Business development is determined by customer loyalty to products produced by SMEs, it is necessary to develop business by applying the principles of Sharia. The results of interviews with the perpetrators of SMEs food products also states that business development is determined by customer loyalty and business doers need to innovate and develop creativity in producing products according to customer wishes.

\subsubsection{Influence of Variable of Implementation of Sharia Principles (X1) Mediated by Business Development Variable (Y1) to Customer Loyalty Variable (Y2)}

The results showed that the implementation of Sharia Principles (X1) mediated by Business Development variables (Y1) to Customer Loyalty Variable (Y2) is significant. The implementation of Sharia principles in business has a very important role in everyday life. A person's concern will be reflected through his/her own ethics. One of the determinants of a person accepted or not in his social environment is determined by his own ethics, as well as in the business world. Businesspersons have a vast space to carry out activities in developing the business undertaken and strive to form a company that is strong, has a high competitiveness. Business actors should manage SMEs well through transparent planning of strategies, systems and procedures supported by a reliable culture and the ethics of SMEs that are carried out consistently. Lately, many violations committed by businesses for business. Increasing competition leads to various ways to survive, although the way done is very harmful to others and violates the ethics in business. Therefore, improving the business climate of a healthy and conducive business ethics is very important to uphold. Ethical behavior in business activity is something that is important for the continuity of business development.

Inconsistencies in business will harm the business itself, especially when viewed from a long-term perspective. A good business morale is a behavior that conforms to the social values upheld in business. In the business world, business people will always have relationships and cooperation with all parties, both inside and outside SME. To keep the relationship going well, business people must have good ethics because ethics in business is one of the factors that determine the success of a business.

4.2.5 Constraints and Expectations of Sharia Businesses in Implementing Sharia Principles in Business. 
Micro, small and medium enterprises are well known in the economic life of Indonesia people, because so far their existence cannot be separated from the national economic growth. SMEs are able to absorb more than 64 million workers and contributed approximately $58.2 \%$ in the formation of gross domestic product (GDP). But we also realize that the facts on the ground prove that the development of SME is still far from expectations. This group has always been the target of development programs of various government institutions.

Ironically, the program does not show the realization of empowerment of their business groups. Most SMEs can only survive at certain turnover sizes. Once he tried to spread his wings, he had to deal with other SMEs products. If it is faced with such a reality, they are powerless and need to increase the turnover for SMEs by winning the competition. For that, SMEs are required to understand the market. If possible, SME not only follow the market development, but able to create market. At present, the exhibition is one of the easiest ways to get to know the market (the consumer). It also allows manufacturers to meet their target market. A number of SME perpetrators complained, it is so difficult to enter a market called exhibition. Not only because of the tight selection, but the funding issue for the SME exhibition which is considered a number of SME doers is still limited. Exhibition abroad is a very rare opportunity for the perpetrators of SMEs, especially SMEs that have grown. Based on the results of interviews with SME actors also stated and indicated that SME still faces classic obstacles so far, both marketing and capital. Capital access constraints, for example, banks are still arguing to apply "prudential banking" to disburse credit.

\section{Conclusions}

Based on the results of research, it can be concluded that:

a. The implementation of Sharia Principles will encourage the increasing of Business Development variable in Pekanbaru City.

b. Implementation of Sharia Principles has not encouraged the increase of Customer Loyalty in Pekanbaru City.

c. The Development of Sharia Business will encourage the increasing of Customer Loyalty in Pekanbaru City.

d. Local governments need to encourage SMEs by helping new businesses grow by providing access to facilities, equipment, training, education, and capital.

\section{References}

[1] Antonio, M. S., 2001. Bank syariah : dari teori ke praktik. 1 ed. Jakarta: Gema Insani.

[2] Beekun, R. I., 1996. Islamics Business Ethics. 2 ed. Herndon, Virginia: The International institute of Islamic Thought.

[3] Bloemer, J., Ruyter, K. \& Wetzels, M., 1998. On the Relationship between store image, store satisfaction, and store loyalty. European Journal of Marketing, Volume 32, pp. 499-513.

[4] Boulding, W., Kalra, A., Staelin, R. \& Zeithaml, V., 1993. A dynamic process model of service quality: form expectations to behavioral intentions. Journal of Marketing Research, Volume 30, pp. 7-27.

[5] Griffin, J., 2002. Customer Loyalty. 2 ed. San Francisco: Jossey- Bass .

[6] Jalil, M. A., 2010. Implementation Mechanism of Ethics in Business Organizations. International Business Research, 3(4), p. 1.

[7] Jones, O. T. \& Sasser, W., 1995. Why Satisfied Customers Defect. Harvard Business Review, 73(6), pp. 89-99. 
[8] Kotler, P., Hayes, T. \& Bloom, P. N., 2002. Marketing Professional Service. s.1.:Prentice Hall International Press..

[9] Liebig, J. E., 1994. Marchants Of Vision. 1 ed. San Francisco: world Business Academy.

[10] Machfoedz, M., 2005. Pengantar Pemasaran Modern. Yogyakarta: YKPN.

[11] Oliver, R. L., 1999. Whence Consumer Loyalty. Journal of Marketing, Volume 63, pp. 33-44.

[12] Olson, F., 1993. The Psychology of Work and Human Performan. 3 ed. New York: addison Wesley Logman Inc.

[13] Reichheld, F., 1996. The Loyalty Effect. Boston: Harvard Business School Press.

[14] Rohmah, S., 2014. http://digilib.uin-suka.ac.id/14964/.[Online] Available at: http://digilib.uin-suka.ac.id/id/eprint/14964 [Accessed 10 Maret 2017].

[15] Stewart, T., 1997. Intellectual Capital:The New Wealth of Organizations. London: Nicholas Brealey.

[16] Sumarwan, U., 2003. Perilaku Konsumen. Jakarta: Ghalia Indonesia. 